\title{
New host records for three saprobic Dothideomycetes in Thailand
}

\author{
Huanraluek $\mathbf{N}^{1}$, Jayawardena $\mathbf{R S}^{1,2^{*}}$, Thambugala $\mathrm{KM}^{3}$ and Tian $\mathbf{Q}^{1}$ \\ ${ }^{1}$ Center of Excellence in Fungal Research, Mae Fah Lunag University, Chiang Rai 57100, Thailand \\ ${ }^{2}$ School of Science, Mae Fah Lunag University, Chiang Rai 57100, Thailand \\ ${ }^{3}$ Genetics and Molecular Biology Unit, Faculty of Applied Sciences, University of Sri Jayewardenepura, Gangodawila, \\ Nugegoda, Sri Lanka
}

Huanraluek N, Jayawardena RS, Thambugala KM, Tian Q 2020 - New host records for three saprobic Dothideomycetes in Thailand. Asian Journal of Mycology 3(1), 345-361, Doi 10.5943/ajom/3/1/9

\begin{abstract}
Three dothideomycetous saprobic species, Clavatispora thailandica, Muyocopron dipterocarpi and Rhytidhysteron neorufulum were collected from dead twigs in Thailand. Multigene phylogenetic analyses confirmed their taxonomic placement. Clavatispora thailandica and Rhytidhysteron neorufulum are reported on Hevea brasiliensis (rubber), while Muyocopron dipterocarpi is described from Mangifera indica (mango) in Thailand for the first time. Newly collected species are compared with other similar species and comprehensive descriptions and micrographs are provided.
\end{abstract}

Key words - Clavatispora - morphology - Muyocopron - phylogeny - Rhytidhysteron

\section{Introduction}

Plant saprobic fungi are specifically adapted to inhabit and utilize dead host plant tissues, and they play a vital role in decomposition, especially as they may produce various wood-decaying enzymes as only a limited group of fungi possess enzymatic capabilities to digest wood. However, some aquatic fungi also produce a rich array of enzymes that are able to degrade the major leaf polysaccharides and some can decay lignin and cause root rot. (Wong et al. 1998, Pointing 2001, Bucher et al. 2004, Cai et al. 2006, Osono 2006). Species of Dothideomycetes often occur as saprobes, mostly on leaves, stems or woods of dicotyledonous plants. Many species are plant pathogens and occur on a wide range of host plants worldwide, they can also be endophytes, epiphytes, fungicolous, lichenized, or lichenicolous fungi. (Zhang et al. 2011, Hyde et al. 2013). Some species can be found on several hosts in different habitats (Hyde et al. 2013, Phillips et al. 2013, Phookamsak et al. 2014, Thambugala et al. 2017a, b). During a survey of saprobic Dothideomycetes in Thailand, we found three dothideomycetous species associated with mango and rubber plants. The current paper presents three new host records from Thailand.

Mango and rubber are agriculturally and economically important plants widespread in tropical and subtropical areas (Jedele et al. 2003). Mango (Mangifera indica L., Anacardiaceae) is native to South Asia, particularly eastern India, Myanmar and Andaman Islands. These trees are distributed throughout the tropics and approximately 50\% of all tropical fruits produced worldwide are mangoes (Morton 1987, Jedele et al. 2003). The rubber plant (Hevea brasiliensis Müll. Arg., Euphorbiaceae) is economically important as the milky latex extracted from this tree is the primary 
source of natural rubber, which is an important raw material with many industrial uses (Ko et al. 2003).

The aim of this paper is to describe some poorly known species, which have been newly collected in Thailand. The descriptions and species identifications are based on morphological characters and DNA sequence data.

\section{Materials \& Methods}

\section{Sample collection, fungal isolation, and morphological study}

Dead twigs of Hevea brasiliensis were collected from Chiang Rai and dead twigs of Mangifera indica were collected from Sukhothai provinces, Thailand. Fungi were isolated by single spore isolation method following Phookamsak et al. (2014). Colony characteristics of the cultures on $2 \%$ malt extract agar (MEA), were observed following growth at room temperature $\left(25^{\circ} \mathrm{C}\right)$. Morphological characters and photomicrographs were recorded using material mounted in water following the methods of Thambugala et al. (2015), Mapook et al. (2016) and Phukhamsakda et al. (2016). Digital images used for figures were processed with Adobe Photoshop CS3 Extended version 10.0 software. Derived isolates were deposited in Mae Fah Luang University Culture Collection (MFLUCC) with duplicates in International Collection of Microorganisms from Plants (ICMP), New Zealand. Dried specimens were deposited in the Herbarium of Mae Fah Luang University (MFLU), Thailand. Facesoffungi numbers and Index Fungorum numbers were obtained following Jayasiri et al. (2015) and Index Fungorum (2020).

\section{DNA extraction, PCR amplification and sequencing}

DNA extraction was carried out with an extraction kit (Biospin Fungus Genomic DNA Extraction Kit, BioFlux ${ }^{\circledR}$, China) using fresh mycelia grown on PDA following the manufacturer's instructions (Hangzhou, P.R. China). Polymerase chain reaction (PCR) amplifications were performed for all the strains with internal transcribed spacers (ITS5/ITS4, White et al. 1990); nuclear ribosomal 28S RNA gene (LR0R/LR5, Vilgalys \& Hester 1990) and nuclear ribosomal 18S RNA gene (NS1/NS4, White et al. 1990) regions; an additional gene region translation elongation factor-1 $\alpha$ (EF1-983F/EF1-2218R, Rehner 2001) was amplified for strain MFLUCC 15-0440, following the conditions and primers mentioned in Thambugala et al. (2017a). The PCR products were visualized under UV light on $1 \%$ agarose electrophoresis gels stained with ethidium bromide. The PCR products were purified and sequenced at Shanghai Sangon Biological Engineering Technology \& Services Co. (Shanghai, P.R. China). All the newly generated sequences were deposited in GenBank (Table 1).

Table 1 Taxa included in the phylogenetic study. The generated in this study are in blue and Extype and ex-epitype in bold.

\begin{tabular}{|c|c|c|c|c|}
\hline \multirow[t]{2}{*}{ Species } & \multirow[t]{2}{*}{ Culture number } & \multicolumn{3}{|c|}{ GenBank accession numbers } \\
\hline & & LSU & SSU & ITS \\
\hline Acrospermum adeanum & M133 & EU940104 & EU940256 & - \\
\hline Acrospermum compressum & M151 & EU940084 & EU940012 & EU940161 \\
\hline Acrospermum gramineum & M152 & EU940085 & EU940013 & EU940162 \\
\hline Botryosphaeria corticis & CBS 119047 & EU673244 & KF766232 & DQ299245 \\
\hline Botryosphaeria dothidea & CBS 115476 & DQ377852 & EU673173 & KF766151 \\
\hline $\begin{array}{l}\text { Botryobambusa } \\
\text { fusicoccum }\end{array}$ & $\begin{array}{l}\text { MFLUCC 11- } \\
0657\end{array}$ & - & JX646827 & - \\
\hline Clavatispora thailandica & $\begin{array}{l}\text { MFLUCC 10- } \\
0107\end{array}$ & KF770458 & KF770457 & - \\
\hline Clavatispora thailandica & $\begin{array}{l}\text { MFLUCC 17- } \\
2237\end{array}$ & MH062960 & МH062967 & MH065721 \\
\hline Diplodia mutila & CBS 112553 & AY928049 & EU673213 & AY259093 \\
\hline
\end{tabular}


Table 1 Continued.

\begin{tabular}{|c|c|c|c|c|}
\hline \multirow[t]{2}{*}{ Species } & \multirow[t]{2}{*}{ Culture number } & \multicolumn{3}{|c|}{ GenBank accession numbers } \\
\hline & & LSU & SSU & ITS \\
\hline Fusicladium cordae & CCF 3843 & FN377748 & - & - \\
\hline Fusicladium cordae & CBS 675.82 & MH873281 & - & MH861540 \\
\hline Fusicladium pini & CBS 463.82 & - & - & MH861517 \\
\hline Fusicladium ramoconidii & CBS 462.82 & MH873263 & - & MH861516 \\
\hline Gloniopsis praelongea & CBS 112415 & FJ161173 & FJ161134 & - \\
\hline Melnikdium vietnamensis & CBS 136209 & MH877613 & - & KJ869156 \\
\hline Muyocopron castanopsis & MFLUCC 10-0042 & - & JQ036225 & - \\
\hline Muyocopron castanopsis & $\begin{array}{l}\text { MFLUCC 14- } \\
1108\end{array}$ & KU726965 & KU726968 & - \\
\hline Muyocopron dipterocarpi & $\begin{array}{l}\text { MFLUCC 14- } \\
1103\end{array}$ & KU726966 & KU726969 & - \\
\hline Muyocopron dipterocarpi & $\begin{array}{l}\text { MFLUCC 17- } \\
2243\end{array}$ & MH062986 & MH062971 & MH065723 \\
\hline Muyocopron garethjones & MFLU 16-2664 & KY070274 & KY070275 & - \\
\hline Muyocopron lithocarpi & MFLUCC 10-0041 & JQ036230 & JQ036226 & - \\
\hline Muyocopron lithocarpi & $\begin{array}{l}\text { MFLUCC 14- } \\
1106\end{array}$ & KU726967 & KU726970 & - \\
\hline $\begin{array}{l}\text { Mycosisymbrium } \\
\text { cirrhosum }\end{array}$ & GUFCC 18012 & KR259884 & KR259885 & KR259883 \\
\hline Neocoleroa metrosideri & PDD 107531 & KU131677 & - & KU131678 \\
\hline Ochroconis constricta & CBS 202.27 & MH866423 & KF156072 & MH854929 \\
\hline Ochroconis humicola & CBS 116655 & KF156124 & KF156068 & - \\
\hline Ochroconis macrozamiae & CBS 1379771 & KJ869180 & KJ869123 & - \\
\hline Ochroconis mirabilis & CBS 729.95 & KF282661 & KF282676 & - \\
\hline Ochroconis musae & CBS 312.96 & KT272083 & KT272093 & KT272078 \\
\hline Ochroconis musae & HLHKBJ22 & JQ364739 & - & JQ364738 \\
\hline Ochroconis podocarpi & CBS 143174 & MG386085 & - & MG386032 \\
\hline Patellaria atrata & CBS 958.97 & GU301855 & GU296181 & - \\
\hline Rhytidhysteron hysterinum & EB 0351 & GU397350 & - & - \\
\hline Rhytidhysteron neorufulum & CBS 306.38 & - & GU296191 & - \\
\hline Rhytidhysteron neorufulum & EB 0381 & GU397351 & GU397366 & - \\
\hline Rhytidhysteron neorufulum & GKM 361A & - & - & GU397342 \\
\hline Rhytidhysteron neorufulum & HUEFS 192194 & KF914915 & - & - \\
\hline Rhytidhysteron neorufulum & MFLUCC 12-0011 & KJ418109 & KJ418110 & KJ206287 \\
\hline Rhytidhysteron neorufulum & MFLUCC 12-0528 & KJ418117 & KJ418119 & KJ418118 \\
\hline Rhytidhysteron neorufulum & MFLUCC 12-0567 & KJ526126 & KJ546129 & KJ546124 \\
\hline Rhytidhysteron neorufulum & MFLUCC 12-0569 & KJ526128 & KJ546131 & KJ546126 \\
\hline $\begin{array}{l}\text { Rhytidhysteron } \\
\text { neorufulum }\end{array}$ & $\begin{array}{l}\text { MFLUCC 13- } \\
0216\end{array}$ & KU377566 & KU377571 & KU377561 \\
\hline Rhytidhysteron neorufulum & MFLUCC 13-0221 & KU377567 & KU377572 & KU377562 \\
\hline $\begin{array}{l}\text { Rhytidhysteron } \\
\text { neorufulum }\end{array}$ & $\begin{array}{l}\text { MFLUCC 17- } \\
2236\end{array}$ & MH063266 & MH062969 & МH062956 \\
\hline Rhytidhysteron rufulum & EB 0382 & GU397352 & - & - \\
\hline Rhytidhysteron rufulum & EB 0383 & GU397353 & GU397367 & - \\
\hline Rhytidhysteron rufulum & EB 0384 & GU397354 & GU397368 & - \\
\hline Rhytidhysteron rufulum & MFLUCC 12-0013 & KJ418111 & KJ418113 & KJ418112 \\
\hline Rhytidhysteron rufulum & MFLUCC 14-0577 & KU377565 & KU377570 & KU377560 \\
\hline Rhytidhysteron sp. & MFLUCC 12-0529 & KJ526124 & KJ546127 & KJ546122 \\
\hline Rhytidhysteron tectonae & $\begin{array}{l}\text { MFLUCC 13- } \\
0710\end{array}$ & - & KU712457 & KU144936 \\
\hline $\begin{array}{l}\text { Rhytidhysteron } \\
\text { thailandicum }\end{array}$ & MFLUCC 12-0530 & KJ526125 & KJ546128 & KJ546123 \\
\hline
\end{tabular}


Table 1 Continued.

\begin{tabular}{|c|c|c|c|c|}
\hline \multirow[t]{2}{*}{ Species } & \multirow[t]{2}{*}{ Culture number } & \multicolumn{3}{|c|}{ GenBank accession numbers } \\
\hline & & LSU & SSU & ITS \\
\hline $\begin{array}{l}\text { Rhytidhysteron } \\
\text { thailandicum }\end{array}$ & $\begin{array}{l}\text { MFLUCC 14- } \\
0503\end{array}$ & KU377564 & KU377569 & KU377559 \\
\hline Scolecobasidiella avellanea & CBS 772.73 & EF204505 & EF204520 & - \\
\hline $\begin{array}{l}\text { Scolecobasidium } \\
\text { excentricum }\end{array}$ & CBS 469.95 & MH874174 & KF282683 & MH862538 \\
\hline Sympoventuria capensis & CBS 120136 & KF156104 & KF156094 & KF156039 \\
\hline Tubeufia chiangmaiensis & $\begin{array}{l}\text { MFLUCC 11- } \\
0514\end{array}$ & KF301538 & KF301543 & KF301530 \\
\hline Tubeufia miscanthi & $\begin{array}{l}\text { MFLUCC 11- } \\
0375\end{array}$ & KF301533 & KF301541 & KF301525 \\
\hline Tubeufia paludosa & CBS 120503 & GU301877 & GU296203 & - \\
\hline Venturia inaequalis & CBS 594.70 & MH87164 & KF156093 & KF156040 \\
\hline Veronaeopsis simplex & CBS 588.66 & KF156103 & KF156095 & EU041820 \\
\hline Verruconis gallopava & CBS 437.64 & KF282656 & KF282636 & HQ667553 \\
\hline Verruconis verruculosa & CBS 119775 & KF156106 & KF156055 & KF156014 \\
\hline
\end{tabular}

\section{Phylogenetic analyses}

Related sequences were obtained from GenBank following recently published papers (Boonmee et al. 2014, Mapook et al. 2016, Thambugala et al. 2016, 2017b). Multi-gene and single gene phylogenetic analyses based on ITS, LSU and SSU sequence data were done to establish the phylogenetic placement of each isolated taxon. Single gene data sets were aligned with BioEdit 7.1.3.0 (Hall 1999) and the consensus sequences were further improved with MUSCLE implemented in MEGA 5v (Tamura et al. 2011). Alignments were checked and optimized manually when necessary. Phylogenetic analyses were based on maximum likelihood (ML) criterion using RAxML-HPC BlackBox (8.2.10) (Stamatakis 2006, Stamatakis et al. 2008) in the CIPRES portal (Miller et al. 2010). The general time reversible model of evolution including estimation of invariable sites with GTRGAMMA + I substitution model (assuming a discrete gamma distribution with four rate categories) was used for the ML analysis. The model for Bayesian inference analysis (BYPP) was determined by using MrBayes 3.2 on XSEDE (Ronquist et al. 2011) in the CIPRES portal (Miller et al. 2010), Simultaneous Markov chains were run for 1,000,000 generations and trees were sampled every $100^{\text {th }}$ generation. The first 1,000 trees, representing the burn-in phase of the analyses, were discarded, while the remaining 9,000 trees were used for calculating posterior probabilities in the majority rule consensus tree. The best scoring tree was selected and visualized with MEGA v. 5 (Tamura et al. 2011) and improved using Adobe Illustrator CS3 software. ML and BYPP bootstrap support (BS) (greater than 60\% ML/0.95 BYPP) are shown above or below each branch. The alignment and trees are deposited in TreeBASE (S23454).

\section{Results}

\section{Phylogenetic analysis}

Three dothideomycetous species, Clavatispora thailandica, Muyocopron dipterocarpi and Rhytidhysteron neorufulum were isolated and sequenced. The data for the aligned sequence matrices for the trees obtained in the different analyses are provided below. Alignments of multigenes were involved, the topologies of the trees for each gene were compared visually to confirm that the overall tree topology of the individual datasets were similar to each other and to that of the tree obtained from the combined alignment.

\section{Clavatispora thailandica (MFLUCC 17-2237)}

The concatenated and single LSU, SSU and ITS datasets comprised 23 strains of species in 
Sympoventuriaceae. The best scoring tree with a final likelihood value of -7252.737610 is presented in Fig. 1. The new isolate of Clavatispora thailandica forms a well-supported (100\% ML/1.00 BYPP) clade with its ex-type strain (MFLUCC 10-0107).

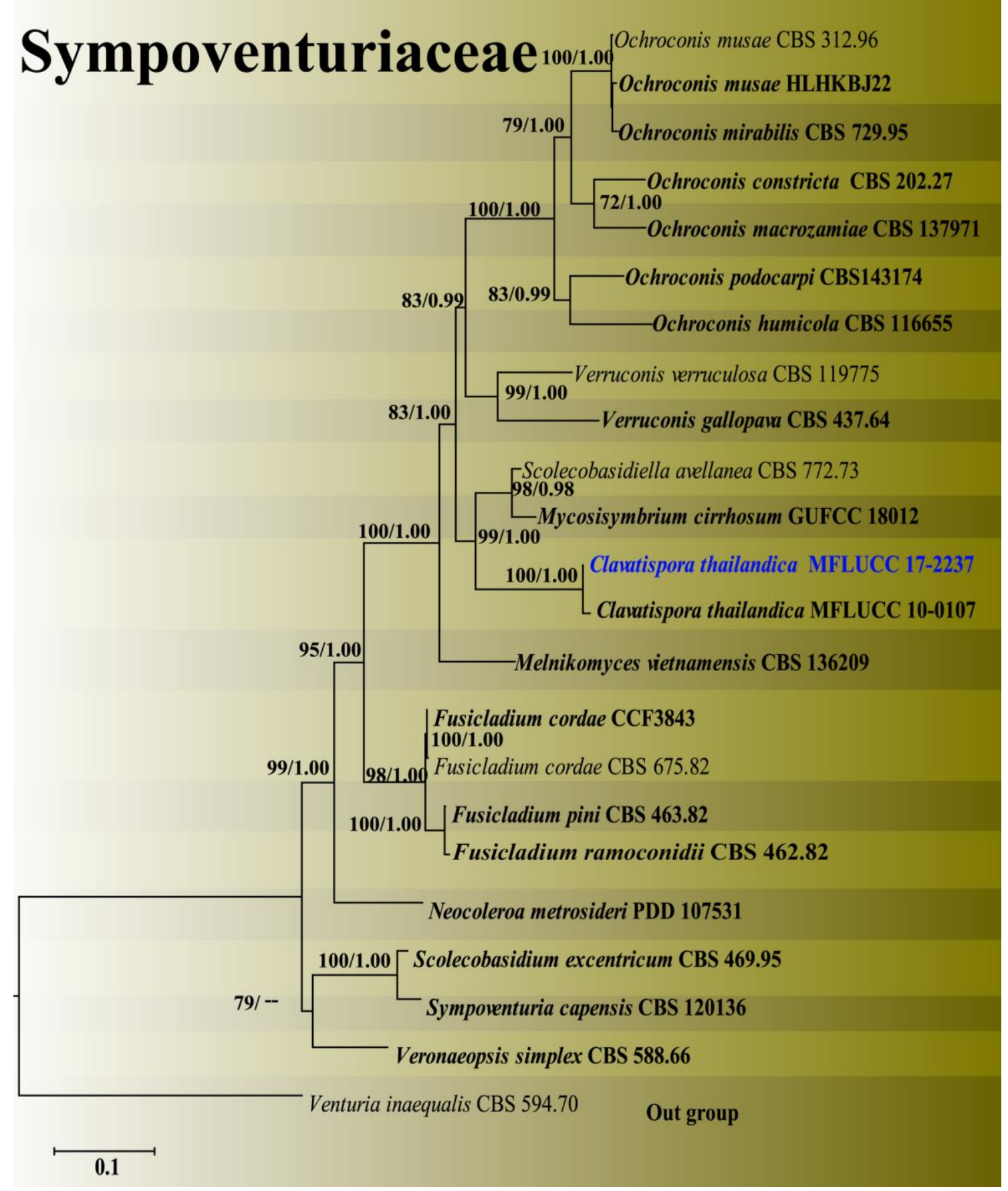

Fig. 1 - Phylogram generated from maximum likelihood tree from analysis of combined LSU SSU and ITS sequence data of species in Sympoventuriaceae. Bootstrap (ML) support values greater than $60 \%$ and BYPP greater than 0.95 are given above or below the nodes. Culture accession numbers are placed after the species name and the tree is rooted to Venturia inaequalis. Ex-type and ex-epitype cultures are in bold and the newly generated Clavatisspora thailandica (MFLUCC 17-2237) is in blue.

\section{Muyocopron dipterocarpi (MFLUCC 17-2243)}

The concatenated and single LSU, SSU and ITS sequence data comprised 18 strains of Acrospermaceae, Botryosphaeriaceae, Muyocopronaceae and Tubeufiaceae species. The best 
scoring tree with a final likelihood value of -6888.564120 is presented in Fig. 2. Muyocopron dipterocarpi (MFLUCC 17-2243) clustered together with its ex-type strain (MFLUCC 14-1103) with good support (100\% ML/1.00 BYPP).

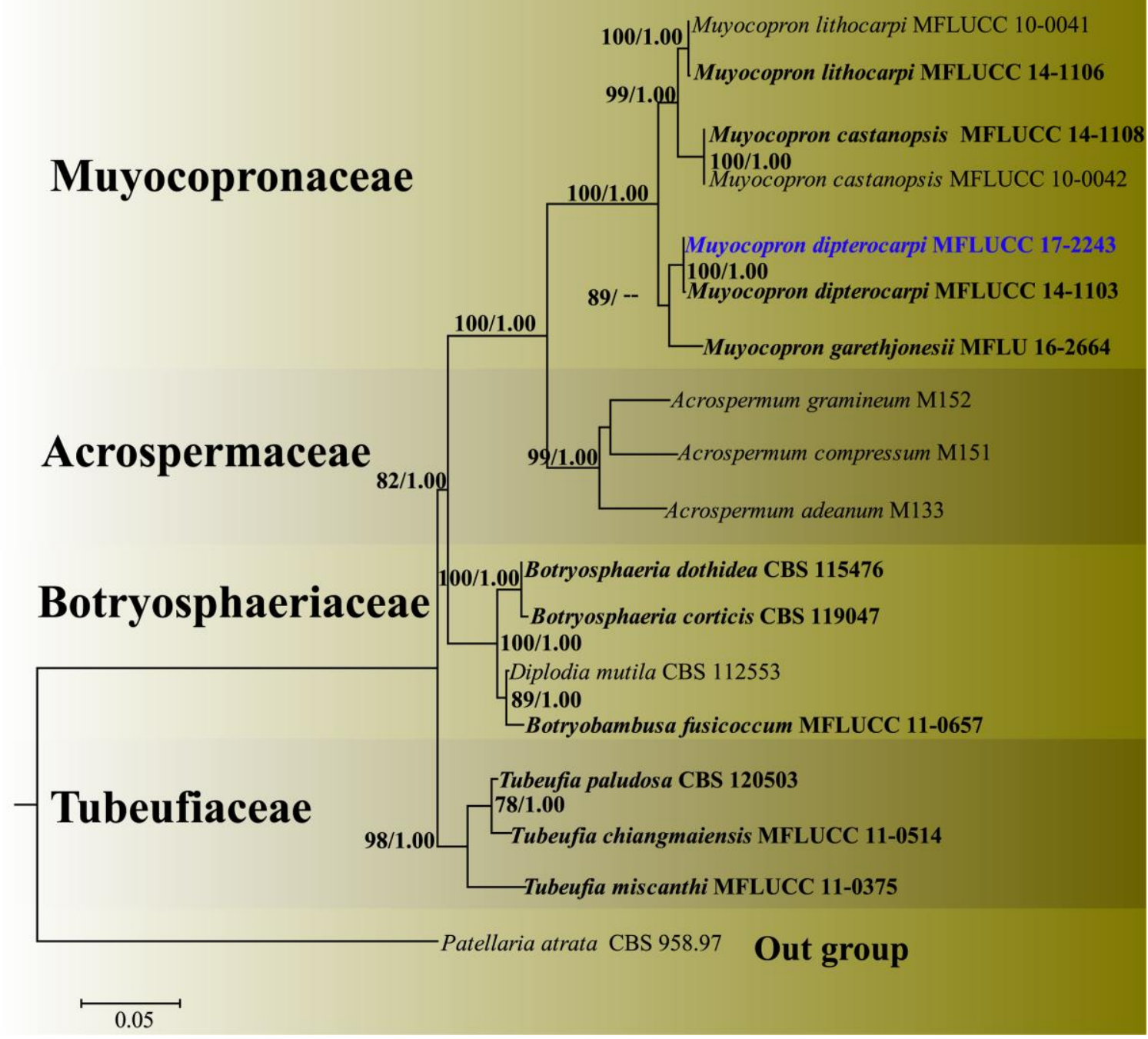

Fig. 2 - Phylogram generated from maximum likelihood tree from analysis of combined LSU SSU and ITS sequence data of species in Acrospermaceae, Botryosphaeriaceae, Muyocopronaceae and Tubeufiaceae. Bootstrap (ML) support values greater than $60 \%$ and BYPP greater than 0.95 are given above or below the nodes. Accession numbers are placed after the species name and the tree is rooted to Patellaria atrata (CBS 958.97). Ex-type and ex-epitype strains are in bold and the newly generated Muyocopron dipterocarpi (MFLUCC 17-2243) is in blue.

\section{Rhytidhysteron neorufulum (MFLUCC 17-2236)}

The concatenated dataset comprised 22 strains of Rhytidhysteron species. The best scoring tree with a final likelihood value of -5562.132998 is presented in Fig. 3. In the resulting phylogenetic analysis, Rhytidhysteron neorufulum (MFLUCC 17-2236) forms a well-supported (0.94 BYPP) clade, sister to $R$. neorufulum (MFLUCC 12-0011) and its ex-type strain (MFLUCC 13-0216).

Venturiales Y. Zhang ter, C.L. Schoch \& K.D. Hyde

Venturiales was introduced by Zhang et al. (2011) based on morphological, ecological and phylogenetic approaches. Some species belonging to this order are plant pathogens and others are saprobes (Hyde et al. 2013, Tibpromma et al. 2018). 


\section{Sympoventuriaceae Y. Zhang ter, C.L. Schoch \& K.D. Hyde}

Zhang et al. (2011) erected Sympoventuriaceae with Sympoventuria Crous \& Seifert as the type genus. This family is characterized by immersed, subglobose ascomata, hyaline septate pseudoparaphyses, bitunicate asci and hyaline, brown to dark brown, oblong, ascospores (Zhang et al. 2011) and also found this family contains the asexual genus as hyphomycetes (Hyde et al. 2013, Wijayawardene et al. 2018), which seven genera Clavatispora Boonmee \& K.D. Hyde., Mycosisymbrium Carris., Ochroconis de Hoog., Sympoventuria, Veronaeopsis Arzanlou \& Crous., Verruconis Samerp., Yunnanomyces Tibpromma \& K.D. Hyde., as well as species from Fusicladium Bonord., Neocoleroa Petr. and Scolecobasidium E.V. Abbott., are referred to the family Sympoventuriaceae based on multi-gene phylogeny (Zhang et al. 2019).

\section{Clavatispora Boonmee \& K.D. Hyde}

Boonmee et al. (2014) introduced Clavatispora Boonmee \& K.D. Hyde in Sympoventuriaceae with $C$. thailandica Boonmee \& K.D. Hyde as the type species and have accepted in Index Fungorum (2020). Clavatispora is characterized by its setiferous, black ascomata, bitunicate asci, with a shrunken ectotunica, endotunica and coloured plasmalemma layers, and clavate, brown to dark brown, muriform ascospores (Boonmee et al. 2014).

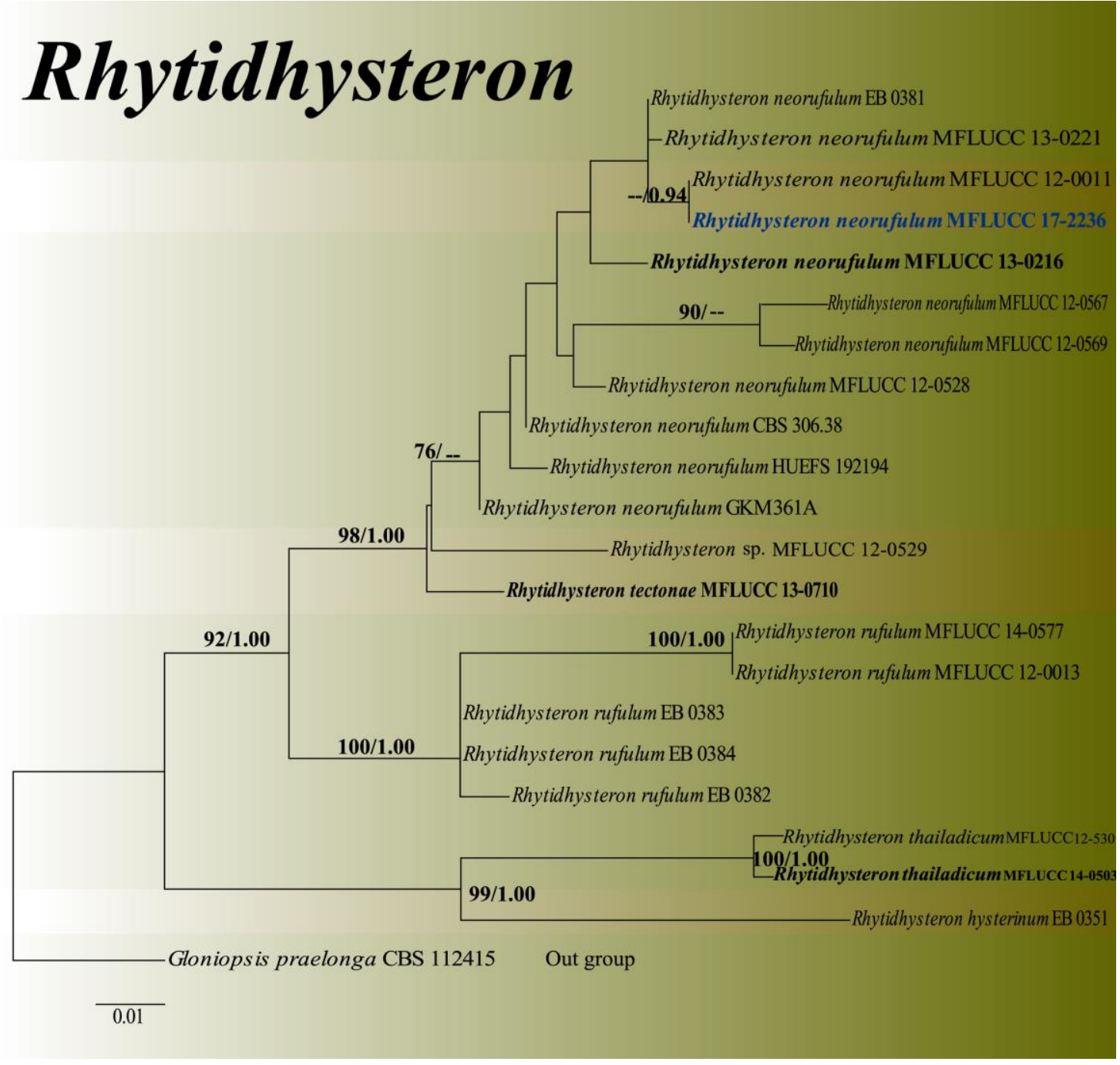

Fig. 3 - Phylogram generated from maximum likelihood tree from analysis of combined LSU, SSU and ITS sequence data of species in Rhytidhysteron. Bootstrap (ML) support values greater than $60 \%$ and BYPP greater than 0.95. Culture accession numbers are given after the species name and the tree is rooted to Gloniopsis praelonga CBS 112415. Ex-type and ex-epitype strains are in bold and the newly generated Rhytidhysteron neorufulum (MFLUCC 17-2236) is in blue. 
Index Fungorum number: IF805924; Facesoffungi number: FoF05124

Saprobic on dead twigs of Hevea brasiliensis. Sexual morph: Ascomata 110-235 $\mu \mathrm{m}$ diam. $\times$ 100-250 $\mu \mathrm{m}$ high, $(\bar{x}=147.3 \times 160.8 \mu \mathrm{m}, \mathrm{n}=10)$ superficial, solitary, scattered, developing on subiculum of brown hyphae, globose to subglobose, dark brown to black, with a bright ostiole covered with 2-3 $\mu \mathrm{m}$ wide, dark brown, thick-walled, septate, strands of radiating setae. Peridium 15-30 $\mu \mathrm{m}$ wide, comprising several layers of dark brown, thick-walled cells of textura angularis, becoming lightly pigmented towards the inner region. Hamathecium comprising 1-2 $\mu \mathrm{m}$ wide, anastomosing, septate, rarely branched pseudoparaphyses, embedded in gelatinous matrix. Asci 60 $100 \times 16-21 \mu \mathrm{m}(\bar{x}=83 \times 18 \mu \mathrm{m}, \mathrm{n}=20), 8$-spored, bitunicate, fissitunicate, to broadly obovoid, with a short pedicel, apically rounded, with an ocular chamber. Ascospores (19-)22-32(-34) $\times 7-$ $10 \mu \mathrm{m}(\bar{x}=27 \times 8.4 \mu \mathrm{m}, \mathrm{n}=45)$, overlapping biseriate, ellipsoidal to fusiform, muriform subclavate, slightly curved, asymmetrical, yellowish when young. becoming reddish brown to dark brown at maturity, 4-7(-8) transversely septate, with 1-2 vertical septa in some cells, deeply constricted at the medium septum, tapering towards a subacute base, smooth-walled. Asexual morph: Hyphomycetous, mycelium slightly raised, hyaline to pale brown, composed of septate, branched, smooth-walled, 1-3 $\mu \mathrm{m}$ wide hyphae. Conidiophores (4-)9-12 $\mu \mathrm{m}$ long $(\bar{x}=8 \mu \mathrm{m}, \mathrm{n}=$ 8 ), erect, developing on hyphae, brown or light brown, septate, smooth, sometimes branched. Conidiogenous cells holoblastic, pale brown, enteroblastic, annelidic, cylindrical, integrated or discrete, determinate, smooth-walled. Conidia (8-)10-13(-14) $\times 3-4(-5) \mu \mathrm{m}(\bar{x}=11 \times 4 \mu \mathrm{m}, \mathrm{n}=$ 20), ellipsoidal to ellipsoidal-cylindrical, hyaline, 0 -1-septate when young, becoming pale brown to brown and 3-septate at maturity, with a large guttule in each cell, rounded at apex, sub-acute at base, slightly constricted at the septa, smooth-walled.

Culture characteristics - Ascospores germinating on PDA within $24 \mathrm{~h}$, germ tubes produced from one end or both ends. Colonies growing on MEA $15 \mathrm{~mm}$ diam. after 11 days at $25^{\circ} \mathrm{C}$, low convex, slightly effuse hairy, edge entire, dark brown smooth, reverse brown, aerial mycelium, radiating outwards, superficial, septate.

Material examined - THAILAND, Chiang rai Province, Mueang District, Weng Chiang, on dead twigs of Hevea brasiliensis, 28 January 2017, Naruemon Huanraluek Rb003 (MFLU 180710; living culture MFLUCC 17-2237, ICMP 22456; GenBank LSU: MH062960, SSU: MH062967, ITS: MH065721.

Known distribution - Thailand (Boonmee et al. 2014) on dead stems, of an unidentified host.

Notes - In the phylogenetic analyses, the new strain (MFLUCC 17-2237) clustered with the ex-type strain of $C$. thailandica (MFLUCC 10-0107, Boonmee et al. 2014) and there is no evidence to suggest that these two strains are phylogenetically different. Nevertheless, a significant difference in ascospore measurements between the two collections were observed Clavatispora thailandica (MFLUCC 10-0107) has larger ascospores $(\bar{x}=37 \times 11 \mu \mathrm{m})$ than $C$. thailandica (MFLUCC 17-2237) $(\bar{x}=27 \times 8.4 \mu \mathrm{m})$. This is the first time any Clavatispora species is recorded from Hevea brasiliensis (Farr \& Rossman 2020).

\section{Muyocopronales Mapook, Boonmee \& K.D. Hyde}

Muyocopronales was introduced by Mapook et al. (2016) and has been placed in the Dothideomycetes. Members of this order are saprobes. Muyocopronales has superficial, flattened, carbonaceous, brittle ascomata, pseudoparaphyses that are longer than the asci and ellipsoidal to ovate, unicellular ascospores.

\section{Muyocopronaceae K.D. Hyde}

Muyocopronaceae was introduced by Luttrell (1951) and included in the order Hemisphaeriales as it has a pleospora-type of centrum similar to most Hemisphaeriaceae, Microthyriaceae and Polystomellaceae (Eriksson 1981). Hyde et al. (2013) accepted Muyocopronaceae as a distinct family with only Muyocopro Speg. in Dothideomycetes. Later Mapook et al. (2016) placed this family in Muyocopronales. Members of this family are saprobic 
on a wide range of host plants and cosmopolitan in distribution (Mapook et al. 2016). In a recent study, a new genus Pseudopalawania Mapook \& K.D. Hyde. was added to Muyocopronaceae, which was found on dead rachis of Arecaceae in Thailand (Mapook et al. 2020).

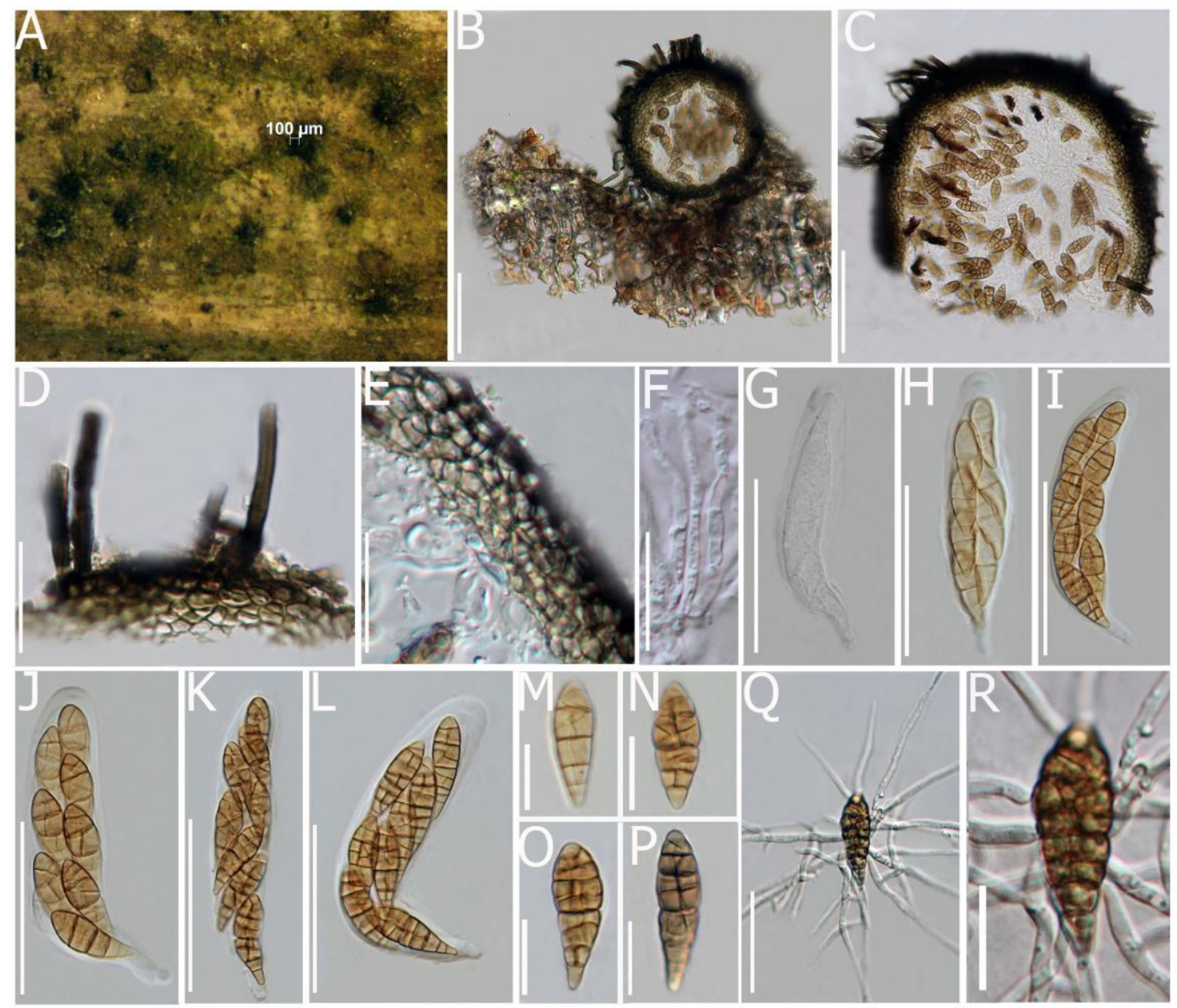

Fig. 4 - Clavatispora thailandica (MFLU 18-0710, sexual morph). A Appearance of ascomata on host surface. B, C Vertical sections through ascomata. D Setae. E Peridium. F Pseudoparaphyses. G-L Immature and mature asci. M-P Ascospores. Q, R Germinated ascospores. Scale bars: B, C = $50 \mu \mathrm{m}, \mathrm{D}-\mathrm{E}=20 \mu \mathrm{m}, \mathrm{F}-\mathrm{L}=50 \mu \mathrm{m}, \mathrm{M}-\mathrm{P}=15 \mu \mathrm{m}, \mathrm{Q}-\mathrm{R}=30 \mu \mathrm{m}$.

\section{Muyocopron Speg}

Muyocopron was introduced by Spegazzini (1881) in Muyocopronaceae (Hyde et al. 2013, Mapook et al. 2016, Wijayawardene et al. 2018). Muyocopron species are saprobic on a wide range of host plants and are cosmopolitan. More than 60 epithets are listed in this genus, but DNA sequence data are available for only a few species (Hyde et al. 2013, Mapook et al. 2016).

Muyocopron dipterocarpi Mapook, Doilom, Boonmee \& K.D. Hyde

Fig. 6

Index Fungorum number: IF 551617; Facesoffungi number: FoF01889

Saprobic on dead twigs of Mangifera indica. Sexual morph: Ascomata 85-180 $\mu \mathrm{m}$ high $\times$ 230-310 $\mu \mathrm{m}$ diam. $(\bar{x}=121.5 \times 279 \mu \mathrm{m}, \mathrm{n}=10)$, superficial, coriaceous, solitary to scattered or aggregated, appearing as circular, flattened, black spots, covering the host surface, without a subiculum, with a poorly developed basal layer and an irregular margin. Ostiole central without setose or hairy appendages, filled with hyaline cells. Peridium $12-40 \mu \mathrm{m}$ wide, widest at the sides, comprising two cell layers, outer layer consisting of dark brown to black, thick-walled cells of textura angularis; inner layer composed of pale brown cells of textura angularis. Hamathecium comprising 1-3 $\mu \mathrm{m}$ wide, cylindrical to filiform, septate pseudoparaphyses, extending above asci. 
Asci 43-60 × 19-29 $\mu \mathrm{m}(\bar{x}=52 \times 24 \mu \mathrm{m}, \mathrm{n}=25), 8$-spored, bitunicate, saccate or broadly obpyriform, short pedicellate to sessile, straight or slightly curved, with an indistinct ocular chamber. Ascospores $14-18(-21) \times 8-12 \mu \mathrm{m}(\bar{x}=16.3 \times 9.7 \mu \mathrm{m}, \mathrm{n}=40)$, multi-seriate or irregularly arranged, partially overlapping, hyaline, oval to obovoid with obtuse ends, aseptate, with or without 1-2 large guttules. Asexual morph: undetermined.

Culture characteristics - Ascospores germinating on PDA within $24 \mathrm{~h}$ and germ tubes produced from one end or both ends. Colonies growing on MEA $20 \mathrm{~mm}$ diam. after 11 days at $25^{\circ} \mathrm{C}$, initially aerial mycelium white, slightly raised, in old cultures grayish to light brown, flattened on surface, dark to dark brown from below, light brown to white margin.

Material examined - THAILAND, Sukhothai Province, Si Satchanalai District, on dead twigs of Mangifera indica, 2 January 2017, Naruemon Huanraluek M1 (MFLU 18-0711; living culture, MFLUCC 17-2243; ICMP 22493; GenBank LSU: MH062986, SSU: MH062971, ITS: MH065723.
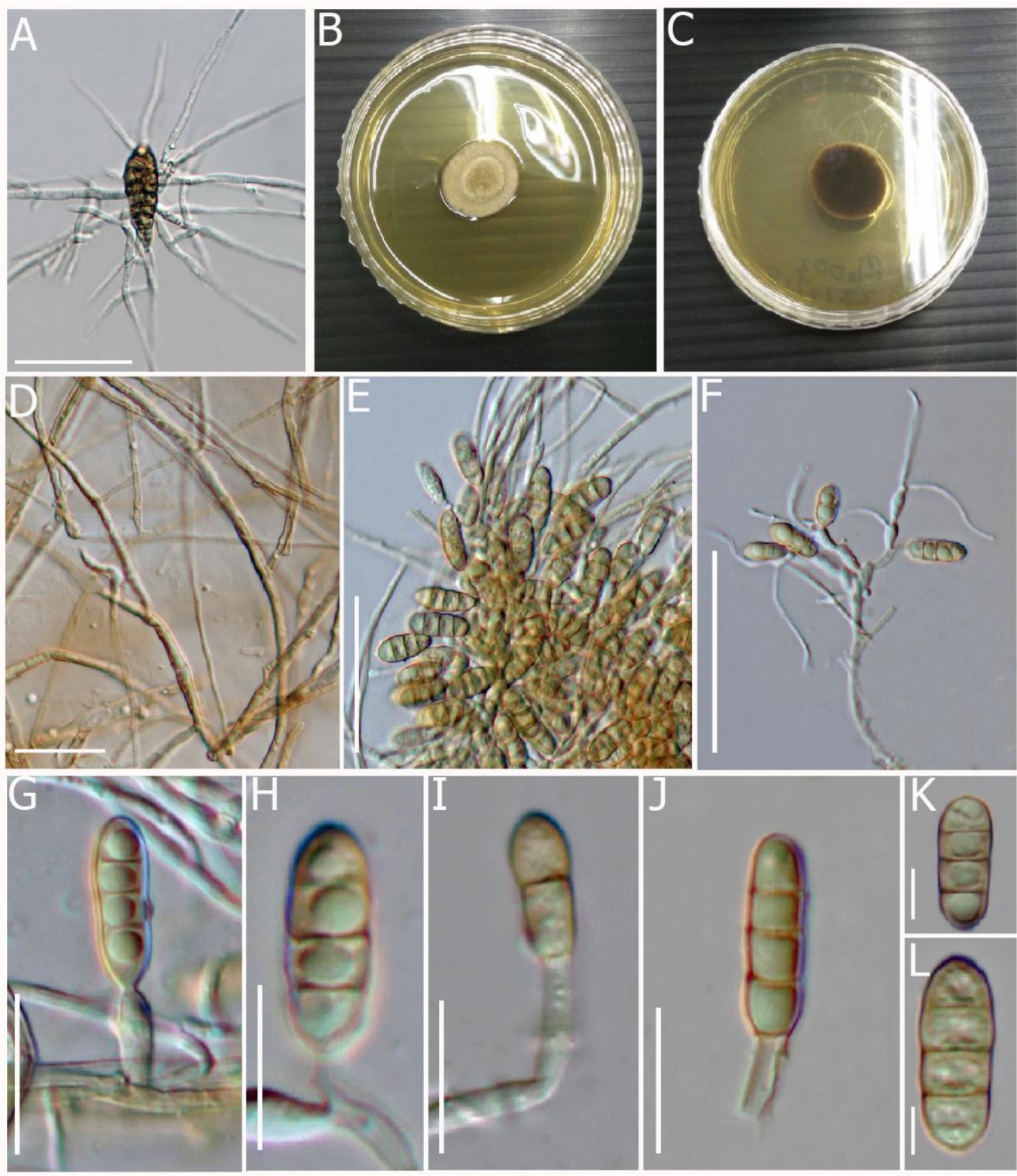

Fig. 5 - Clavatispora thailandica (MFLUCC 17-2237, asexual morph). A Germinating conidium. B-C Culture morphology on MEA, $15 \mathrm{~mm}$ after 11 days (note $\mathrm{C}$ reverse). D Vegetative hyphae 
formed in culture. E-I Conidiophores and developing conidia. J-L Conidia. Scale bars: $\mathrm{A}=30 \mu \mathrm{m}$, $\mathrm{D}=20 \mu \mathrm{m}, \mathrm{E}-\mathrm{I}=15 \mu \mathrm{m}, \mathrm{J}-\mathrm{L}=10 \mu \mathrm{m}$.
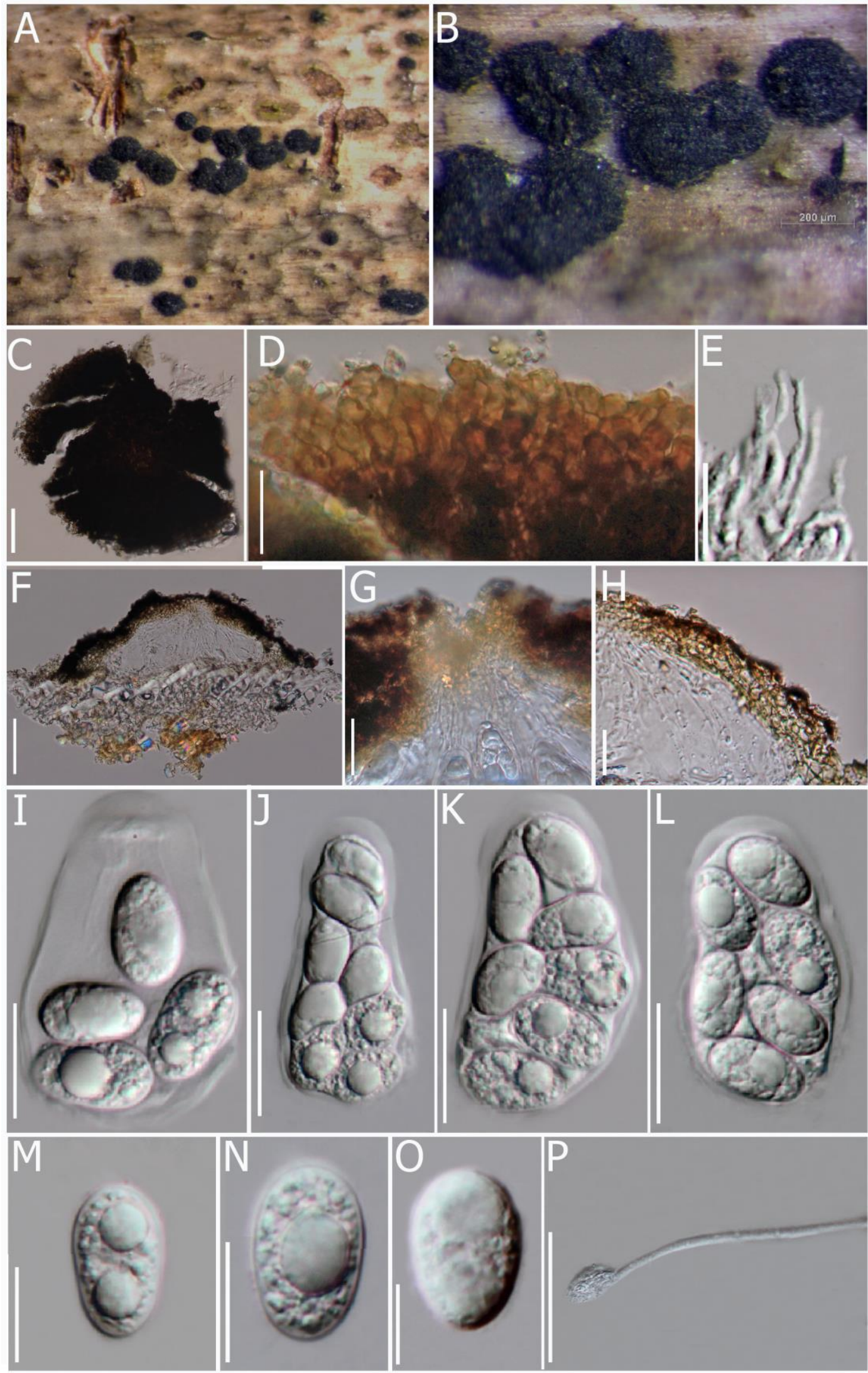

Fig. 6 - Muyocopron dipterocarpi (MFLU 18-0711). A, B Appearance of ascomata on host. C Squash mount of ascoma. D Ascomata wall. E Pseudoparaphyses. F Vertical section through 
ascoma. G Apex of ascoma. H Peridium. I-L Asci. M-O Ascospores. P Germinating ascospore. Scale bars: $\mathrm{C}=100 \mu \mathrm{m}, \mathrm{D}-\mathrm{H}, \mathrm{I}-\mathrm{L}=20 \mu \mathrm{m}, \mathrm{F}=70 \mu \mathrm{m}, \mathrm{M}-\mathrm{O}=10 \mu \mathrm{m}, \mathrm{P}=50 \mu \mathrm{m}$.

Known distribution - Thailand, on hosts Dipterocarpus tuberculatus (Mapook et al. 2016), Hevea brasiliensis (Senwanna et al. 2019).

Notes - Muyocopron dipterocarpi was introduced from dried twigs of Dipterocarpus tuberculatus (Dipterocarpaceae) in Thailand. The new collection on dead twigs of Mangifera indica fits well with the protologue (Mapook et al. 2016). In the phylogenetic analyses, the new strain clusters with the type strain of $M$. dipterocarpi (MFLUCC 14-1103) and together they form a well-supported clade (100\% ML/1.00 BYPP). However, M. dipterocarpi (MFLUCC 14-1103) has larger ascomata $(\bar{x}=110 \times 256.5 \mu \mathrm{m})$ than the type strain (MFLUCC 17-2243). This is the first time a Muyocopron species has been recorded from Mangifera indica (Farr \& Rossman 2020)

\section{Hysteriales Lindau}

Hysteriales was introduced by Lindau (1897) and this order has been placed among the Pyrenomycetes and the Discomycetes at different times by various authors (Rehm 1896). However, molecular data places Hysteriales in Dothideomycetes (Boehm et al. 2009a, b, Shearer et al. 2009, Suetrong et al. 2009, Hyde et al. 2013, Thambugala et al. 2016, Jayasiri et al. 2018).

\section{Hysteriaceae Chevall.}

Hysteriaceae was introduced by Chevallier (1826) in Hysteriales (Boehm et al. 2009a, b, Hyde et al. 2013, De Almeida et al. 2014, Wijayawardene et al. 2014). Based on morphological and phylogenetic data, this family comprises nine genera: Gloniopsis De Not., Graphyllium Clem., Hysterium Pers., Hysterobrevium E. Boehm \& C.L. Schoch., Hysterodifractum D.A.C. Almeida, Gusmão \& A.N. Mill., Oedohysterium E. Boehm \& C.L. Schoch., Ostreichnion Duby., Psiloglonium Höhn. and Rhytidhysteron Speg. However, based on morphology alone, Actidiographium Lar.N. Vassiljeva., Gloniella Sacc., Hysterocarina H. Zogg. and Hysteropycnis Hilitzer. also belong to Hysteriaceae (Boehm et al. 2009a, b, Wijayawardene et al. 2018, Jayasiri et al. 2018).

\section{Rhytidhysteron Speg.}

Thambugala et al. (2016) revised the genus Rhytidhysteron, introduced two new species and showed the presence of striations on the surface of ascomata as a distinct character to delimit species in this genus. The ascomata of Rhytidhysteron are often thought of as hysterothecial as the genus belongs in Hysteriales in Dothideomycetes. Thambugala et al. (2016) mentioned that the ascomata of Rhytidhysteron species were hysterothecial, however, the ascomata of Rhytidhysteron species are hysterothecium-like when young or dry, having their margin incurved, but they are completely open, revealing the hymenium, at maturity (or when moist). Twenty-two epithets are listed in Index Fungorum (2020).

Rhytidhysteron neorufulum Thambugala. \& K.D. Hyde

Fig. 7

Index Fungorum number: IF 551617; Facesoffungi number: FoF01840

Saprobic on dead twigs of Hevea brasiliensis. Sexual morph: Ascomata 271-364 long $\times 310$ 464 diam. $(\bar{x}=311 \times 400 \mu \mathrm{m}, \mathrm{n}=4)$, apothecioid, solitary to aggregated, superficial, black, carbonaceous to coriaceous, elliptic, compressed at apex or irregular in shape, with lenticular or irregular opening when wet, not striate, black or yellow at the center, when dry folded at the margin, forming an elongate slit. Exciple 75-190 $\mu \mathrm{m}$ wide, comprising several layers of dark brown to black, thick-walled cells of textura angularis becoming somewhat flattened and lightly pigmented towards the inner region. Hamathecium comprising 2-3 $\mu \mathrm{m}$ wide, dense, septate pseudoparaphyses, forming epithecium above the asci and enclosed in a gelatinous matrix turning blue when stained with Melzer's reagent. Asci 160-210 $\times 10-15 \mu \mathrm{m}(\bar{x}=185 \times 12.5 \mu \mathrm{m}, \mathrm{n}=15)$, 8-spored, bitunicate, clavate to cylindrical, with a short, furcate pedicel, apically rounded, without a 
distinct ocular chamber. Ascospores 25-29 $\times 8-11 \mu \mathrm{m}(\bar{x}=26 \times 9.2 \mu \mathrm{m}, \mathrm{n}=40)$, uni-seriate, slightly overlapping, ellipsoidal to fusiform, slightly rounded or pointed at both ends, 1-septate and hyaline to yellowish when young, becoming 3-septate and reddish brown to brown at maturity, smooth-walled, guttulate, without a mucilaginous sheath. Asexual morph: undetermined.
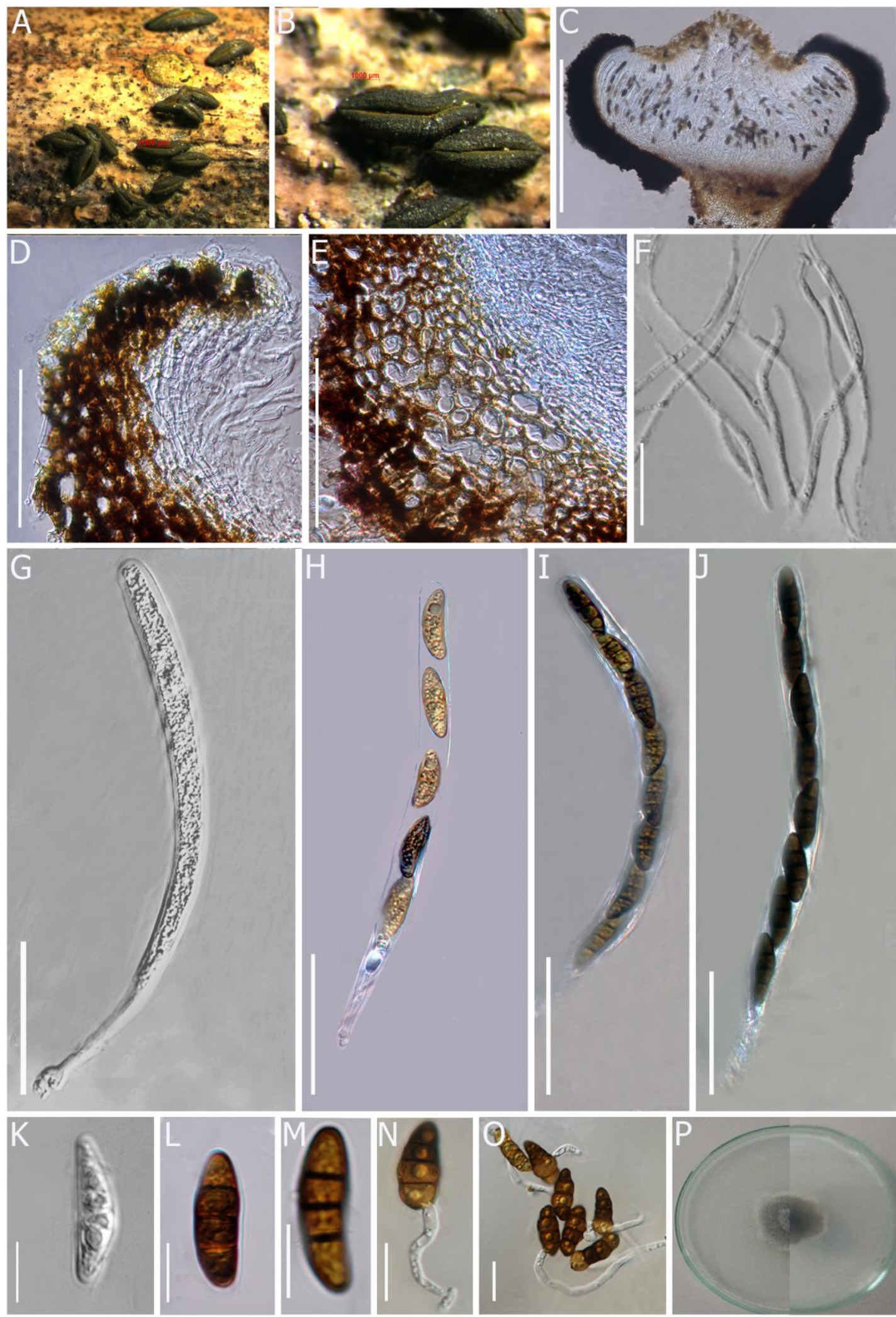

Fig. 7 - Rhytidhysteron neorufulum (MFLU 18-0641). A-B Appearance of ascomata on host. C Vertical section through ascoma. D, E Exciple. F Pseudoparaphyses. G, H Immature asci. 
I-J mature asci. $\mathrm{K}-\mathrm{M}$ Ascospores. $\mathrm{N}-\mathrm{O}$ Germinating ascospore. $\mathrm{P}$ Colony on PDA. Scale bars: $\mathrm{C}=$ $400 \mu \mathrm{m}, \mathrm{D}-\mathrm{E}, \mathrm{H}-\mathrm{J}=50 \mu \mathrm{m}, \mathrm{F}, \mathrm{G}, \mathrm{N}, \mathrm{O}=20 \mu \mathrm{m}, \mathrm{K}-\mathrm{M}=10 \mu \mathrm{m}$.

Culture characteristics - Ascospores germinating on MEA within $24 \mathrm{~h}$ and germ tubes produced from one end or both ends. Colonies growing on MEA $20 \mathrm{~mm}$ diam. after 10 days at $25^{\circ} \mathrm{C}$, irregular, raised, dense, surface white, reverse saffron to reddish brown, margin yellowish, smooth surface with undulate edge.

Material examined - THAILAND, Chiang Rai Province, Mueang District, on dead twigs of Hevea brasiliensis, 26 December 2016, Naruemon Huanraluek, Rb002 (MFLU 18-0641); living culture MFLUCC 17-2236; ICMP 22179; GenBank LSU: MH063266, SSU: MH062969, ITS: MH062956.

Known distribution - Thailand, Chiang Rai Province, on dead stem and Chiang Mai Province, on dead wood and in Phitsanulok Province, on dead wood. (Thambugala et al. 2016)

Notes - Rhytidhysteron neorufulum was introduced by Thambugala et al. (2016) and found on twigs and dead wood from Chiang Rai, Chaing Mai and Phitsanulok. It is characterized by superficial apothecioid carbonaceous to coriaceous ascomata without striations (Thambugala et al. 2016, Hyde et al. 2017). The new strain clusters with the strain of $R$. neorufulum (MFLUCC 120011) well-supported clade (0.94 BYPP). However, $R$. neorufulum (MFLUCC 12-0011) has larger ascomata than the $R$. neorufulum MFLUCC 17-2236 strain (Thambugala et al. 2016). This is the first record of a Rhytidhysteron species from Hevea brasiliensis (Farr \& Rossman 2020).

\section{Discussion}

Fungal saprobes play a major role in the decomposition of organic matter in nature (Wong et al. 1998, Cai et al. 2006), which helps to maintain ecological balance. We made new collections of three saprobic fungi. Clavatispora thailandica is morphology identical to the type species and in the phylogenetic analyses it the clustered with the ex-type strain of $C$. thailandica (Fig. 1).

Muyocopron dipterocarpi was collected from dead twigs of Mangifera indica from Sukhothai and have similar morphology to the ex-type strain of M. dipterocarp (Mapook et al. 2016) and in the phylogenetic analyses, our strain clustered with the type strain of $M$. dipterocarpi.

Rhytidhysteron neorufulum found on Hevea brasiliensis in Chiang Rai, showed similar morphology and in the phylogenetic analyses, it clustered with the type strain of $R$. neorufulum (Thambugala et al. 2016).

The above fungi were reported on different host species, which resulted in new host records from Thailand. Expanding collections of saprobic micro-fungi on different hosts may lead to the identification of new host and geographical records for these fungi.

\section{Acknowledgements}

Authors would like to thank Mae Fah Luang University and Kevin D. Hyde.

\section{References}

Boehm EWA, Schoch CL, Spatafora JW. 2009a - On the evolution of the Hysteriaceae and Mytilindiaceae (Pleosporommycetidae, Dothideomycetes, Ascomycota) using four nuclear genes. Mycological Research 113, 461-479.

Boehm EWA, Mugambi GK, Miller AN, Huhndorf SM et al. 2009b - A molecular phylogenetic reappraisal of the Hyseteriaceae, Mytilindiaceae and Gloniaceae (Pleosporommycetidae, Dothideomycetes) with keys to world species. Studies in Mycology 64, 49-83.

Boonmee S, Bhat JD, Maharachchikumbura SS, Hyde KD. 2014 - Clavatispora thailandica gen. et sp. nov, a novel taxon of Venturiales (Dothideomycetes) from Thailand. Phytotaxa 176, 92101.

Bucher VVC, Hyde KD, Pointing SB, Reddy CA. 2004 - Production of wood decay enzymes, mass loss and lignin solubilization in wood by marine ascomycetes and their anamorphs. Fungal 
Diversity $15,1-14$.

Cai L, Ji KF, Hyde KD. 2006 - Variation between freshwater and terrestrial fungal communities on decaying bamboo culms. Antonie van Leeuwenhoek 89, 293-301.

Chevallier FF. 1826 - Flore générale des environs de Paris, vol I. Ferra Librairie-Editeur, Paris.

De Almeida DAC, Gusmão LFP, Miller AN. 2014 - A new genus and three new species of hysteriaceous ascomycetes from the semiarid region of Brazill. Phytotaxa 176, 298-308.

Eriksson OE. 1981 - The families of bitunicate Ascomycetes. Opera Botanica 60, 1-209.

Farr DF, Rossman AY. 2020 - Fungal Databases, U.S. National Fungus Collections Fungus-Host Database, ARS, USDA. (Retrieved on April 3, 2020)

Hall TA, 1999 - BioEdit: a user-friendly biological sequence alignment editor and analysis program for Windows 95/98/NT. Nucleic Acids Symposium Series 41, 95e98

Hyde KD, Jones EBG, Liu JK, Ariyawansa H et al. 2013 - Families of Dothideomycetes. Fungal Diversity 63, 1-313.

Hyde KD, Norphanphoun C, Abreu VP, Bazzicalupo A et al. 2017 - Fungal Diversity notes 603708: taxonomic and phylogenetic notes on genera and species. Fungal Diversity 87, 1-235.

Index Fungorum. 2020 - http://www.index fungo rum.org/Names/Names.asp

Jayasiri SC, Hyde KD, Ariyawansa HA, Bhat J et al. 2015 - The Faces of Fungi database: fungal names linked with morphology, phylogeny and human impacts. Fungal Diversity 74, 3-8.

Jayasiri SC, Hyde KD, Jones EBG, Peršoh D et al. 2018 - Taxonomic novelties of hysteriform Dothideomycetes. Mycosphere 9, 803-837.

Jedele S, Hau AM, von Oppen M. 2003 - An analysis of the world market for mangos and its importance for developing countries. In: Conference on International Agricultural Research for Development (Vol. 1). October 8-10, Göttingen, Germany.

Ko JH S, Han KH. 2003 - Transcriptome analysis reveals novel features of the molecular events occurring in the laticifers of Hevea brasiliensis (para rubber tree). Plant Molecular Biology $53,479-492$.

Lindau G. 1897 - Hysteriineae. In: Engler \& Prantl, Naturliche Pflanzenfamilien. I. Teil, I. Abteilung. 1, 265-278.

Luttrell ES. 1951 - Taxonomy of Pyrenomycetes. University of Missouri Studies 24, 1-120.

Mapook A, Hyde KD, Dai DQ, Li J et al. 2016 -Muyocopronales, ord. nov., (Dothideomycetes, Ascomycota) and a reappraisal of Muyocopron species from northern Thailand. Phytotaxa 265, 225-237.

Mapook A, Macabeo APG, Thongbai B, Hyde KD. 2020 - Polyketide-Derived Secondary Metabolites from a Dothideomycetes Fungus, Pseudopalawania siamensis gen. et sp. nov., (Muyocopronales) with Antimicrobial and Cytotoxic Activities. Biomolecules 10, 569.

Miller MA, Pfeiffer W, Schwartz T. 2010 - Creating the CIPRES Science Gateway for inference of large phylogenetic trees. In Proceedings of the Gateway Computing Environments Workshop (GCE), 14 November. 2010, New Orleans, Los Angeles, pp, 1-8.

Morton JF. 1987 - Fruits of warm climates. New CROP, New Crop Resource Online Program, Center for New Crops \& Plant Products, Purdue University. pp. 221-239.

Osono T. 2006 - Role of phyllosphere fungi of forest trees in the development of decomposer fungal communities and decomposition processes of leaf litter. Canadian Journal of Microbiology 52, 701-716.

Phillips AJL, Alves A, Abdollahzadeh J, Slippers B Wingfield MJ et al. 2013 - The Botryosphaeriaceae: genera and species known from culture. Studies in Mycology 76, 51167.

Phookamsak R, Liu JK, McKenzie EHC, Manamgoda DS Ariyawansa A et al. 2014 - Revision of Phaeosphaeriaceae. Fungal Diversity 68, 159-238.

Phukhamsakda C, Ariyawansa HA, Phillips AJL, Wanasinghe DN et al. 2016 - Additions to Sporormiaceae: Introducing two novel genera, Sparticola and Forliomyces, from Spartium. Cryptogamie, Mycologie 37, 75-97. 
Pointing SB. 2001 - Exploiting of versatile ligninolytic system of white-rot fungi. Fungal Diversity 6, 253-290.

Rehm H. 1896 - Ascomyceten: Hysteriaceen and Discomyceten, In L. Rabernhorst's KryptogamenFlora von Deutschland, Oesterreich und der Schweiz. 2nd Ed, Eduard Kummer, Leipzig 3, 156.

Rehner S. 2001 - Primers for elongation factor 1- $\alpha(E F 1-\alpha)$. http://ocid. NACSE.ORG/research/deephyphae/EF1primer.pdf

Ronquist F, Huelsenbeck J, Teslenko M. 2011 - Draft MrBayes version 3.2. Manual: tutorials and model summaries. Bioinformatics 85-131.

Senwanna C, Hongsanan S, Phookamsak R, Tibpromma S et al. 2019 - Muyocopron heveae sp. nov. and $M$. dipterocarpi appears to have host-jumped to rubber. Mycological Progress 18, 741-752.

Shearer CA, Raja HA, Miller AN, Nelson P et al. 2009 - The molecular phylogeny of freshwater Dothideomycetes. Studies in Mycology 64, 145-153.

Spegazzini CL. 1881 - Fungi argentini additis nonnullis brasiliensibus montevideensibusque. Pugillus quartus (Continuacion) Anales de la Sociedad Científica Argentina 12, 97-117.

Stamatakis A. 2006 - RAxML-VI-HPC: Maximum likelihood-based phylogenetic analyses with thousands of taxa and mixed models. Bioinformatics 22, 2688-2690.

Stamatakis A, Hoover P, Rougemont J. 2008 - A rapid bootstrap algorithm for the RAxML Web servers. Systematic Biology 57, 758-771.

Suetrong S, Schoch CL, Spatafora JW, Kohlmeyer J et al. 2009 - Molecular systematics of the marine Dothideomycetes. Studies in Mycology 64, 155-173.

Tamura K, Peterson D, Peterson N, Stecher G et al. 2011 - MEGA5: molecular evolutionary genetics analysis using maximum likelihood, evolutionary distance, and maximum parsimony methods. Molecular Biology and Evolution 28, 2731-2739.

Thambugala KM, Hyde KD, Tanaka K, Tian Q et al. 2015 - Towards a natural classification and backbone tree for Lophiostomataceae, Floricolaceae, and Amorosiaceae fam. nov. Fungal Diversity 74, 199-266.

Thambugala KM, Hyde KD, Eungwanichayapant PD, Romero AI, Liu ZY. 2016 - Additions to the genus Rhytidhysteron in Hysteriaceae. Cryptogamie Mycologie 37, 99-116.

Thambugala KM, Daranagama DA, Phillips AJL, Bulgakov TS et al. 2017a - Microfungi on Tamarix. Fungal Diversity 82, 239-306.

Thambugala KM, Wanasinghe DN, Phillips AJL, Camporesi E et al. 2017b - Mycosphere notes 150: grass (Poaceae) inhabiting Dothideomycetes. Mycosphere 8, 697-796.

Tibpromma S, Hyde KD, McKenzie EHC, Bhat DJ. 2018 - Fungal diversity notes 840-928: microfungi associated with Pandanaceae. Fungal Diversity 93, 1-160.

Vilgalys R, Hester M. 1990 - Rapid genetic identification and mapping of enzymatically amplified ribosomal DNA from several Cryptococcus species. Journal of Bacteriology 172, 4238-4246.

White T, Bruns T, Lee S, Taylor J. 1990 - Amplification and direct sequencing of fungal ribosomal RNA genes for phylogenetics. PCR protocols: a guide to methods and applications 18, 315322.

Wijayawardene NN, Crous PW, Kirk PM, Hawksworth DL et al. 2014 - Naming and outline of Dothideomycetes-2014 including proposals for the protection or suppression of generic names. Fungal Diversity 69, 1-55.

Wijayawardene NN, Hyde KD, Lumbsch HT, Liu JK et al. 2018 - Outline of Ascomycota: 2017. Fungal Diversity 88, 167-263.

Wong MK, Goh TK, Hodgkiss IJ, Hyde KD et al. 1998 - Role of fungi in freshwater ecosystems. Biodiversity \& Conservation. 7, 1187-1206.

Zhang SN, Liu JK, Jones EBG, Cheewangkoon R. 2019 - Morphology and phylogeny of Yunnanomyces phoenicis sp. nov. (Sympoventuriaceae) from Thailand. Asian Journal of Mycology 2, 213-221. 
Zhang Y, Crous PW, Schoch CL, Bahkali AH et al. 2011 - A molecular, morphological and ecological reappraisal of Venturiales - a new order of Dothideomycetes. Fungal Diversity 51, 249-277. 